\title{
THE INFLUENCE OF SPEECH STIMULATION UPON SPONTANEOUS BLING AND ITS APPLICATION TO OBJECTIVE AUDIOMETRY.
}

\author{
By \\ S. SHIROSHITA \\ From the Department of Otolaryngology, Faculty of Medicing Hokkaido \\ University. (Director: Prof. S. Hirano)
}

The influence of speech-stimulation upon spontaneous blinking was investigated with electrcoculogram, and attempt was made to measure the hearing for speech by means of its application.

The following are the major findings;

1. In 40 cases $(74.0 \%)$ out of 54 cases, which consisted of 30 cases with normal hearing and 24 cases with hard of hearing the inhibition or the facillitation of spontaneoos blinking was observed when speech stimulation was given.

Inhibition type was found in 33 cases $(82.5 \%)$ and Facillitation type was found in 7 cases $(17.5 \%)$.

2. Cases who shwed the difference of less than $0 \pm 12.5 \mathrm{db}$ between the threshold of the objective method (pure tone threshold, speech perception threshold, and speech discrimination threshold) were $80 \%$ in pure tone threshold, $92.3 \%$ in speech perception threshold and $84.6 \%$ in speech discrimiation threshold.

3. From these results, the abovementioned method is considered to have possibility in clinical application as one of the objective audiometries.

\section{自発瞬目におよぼす語音刺激の影響と，その他覚的 聴力桧查への応用}

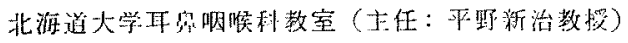

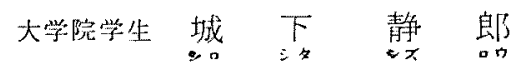

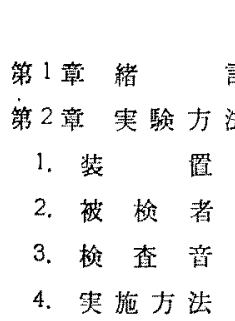

第 3 章 䒠䍄成紪

1. 正常噹力者についての実験成維
(1) 反応陽制率
(2) 反店㻎式
(3) 聴力測定成續

2. 難㯖者についての実監成絽
(1) 反店陽性努

(2) 反応型式

(3) 瞣少测定成綪

第4 章 蚣括ならびに考按

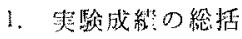

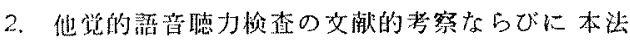
成維!との比校

3. 本现象発现の機序

4. 本法比刘する批判

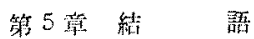

参考交献

\section{第 1 章 緒 言}

近時電子工策の発達と共に優秀なオージメーターが 
作製されそそれによつて精密な恥力の湘定が可能になつ たが、自覚的応管の不可能な，またはそれができてもと の意志のない, 乳奻胃, 精洲病者, 詐病者では测定がで きないそこで患者の自賞的応答を必要としない他覚的 な聴力湘定法が必要とされてきた、現在までの他賞的聴 力測定法を、音剌激に刘する反応の型式から分類する

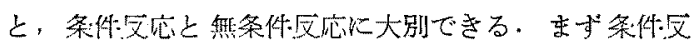
応を利用した聴力娭盐としては，Bordley 1)，渿本 2)，

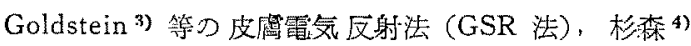
の逗孔反応に上る法. 吉江 ${ }^{5}$ の瞬目反応による法、本

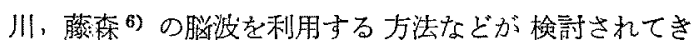
たが，いずれにも難点があり，まだ完全な方法とはなつ ていないようである。次に無条件反応による方法として

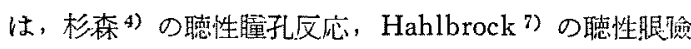
反応，浅輸8）の絪波による法，下平，他9）の GSR 法 などがあるが，その多くは弱、音に対しては民応が現れ ず，聴力䦪值上かなり強い音を用いなければならないの で精度の点に欠点があると云わなければならない，

以上は純音による他筧的聴検法であるが，最近，Knapp ¿ Gold ${ }^{10)}$ Ruhm ¿ Menzel ${ }^{11}$ ) Whipple と Kodman ${ }^{12)}$ 等は語音を用いGSR 法により聴力を測定 し、かなり見るべき成績を上げている、さて，動物に音 や光等の束激を与克ると当初はその剌激の方へ顔を向け る反応が見られる、これは詮系反応といわれ，また心理 学的には注难集中 (Attention) に伴与現象ともみられ ている (Lindsley 13)). 同様な現象は人間に执いても諗 められ，とくに艺の個人の注意を引的起こすような聴覚

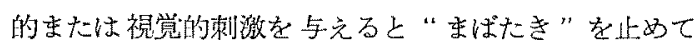
刺激の万を注梘することは日常よく経駼するところです

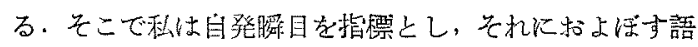

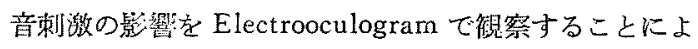
つて暗力の他觉的䁌定を試みた.

\section{第 2 章 実験方法}

1, 㥄 置

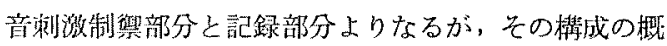
要を第 1 図に示す

(1) 学赖激制隽部分

語音刺激はシールドルーム外飞置かれたテープレコー ダーよりオージオメーター(小林理研, A1002D 型)， 制䉂スイッチを経てシールドルーム内の受話器に達す る・

(2) 記録部分

音刺激記録部分; 制售スイッチより直接オッシログ
ラフに入つて記録される。

瞬目反応記録部分；瞬目により眼球が内上菭し 絽膜 静止電位の変動が生ずる事笑 (本川 ${ }^{14)}$ )か. ulogram（広石 ${ }^{15}$ ) を用いて自発瞬目を記録した。すな わらこの電位変動は上下腿简緣中央に固定された 2 枚の 值经 $3 \mathrm{~mm}$ の銀板電極より增幅器 (日本光電 $\mathrm{AD} Z-1$ ) に入り直記式オッシログラフ（日本光電 WI-20)で記 録された。

2. 被 检 者

正常聴力者 30 名 (12才〜50才) 之難㯖者 25 名（4才 〜75才), 計 55 名であつた。

\section{3. 检查音}

井代鯂二著“本日休診” の最初の数頁を時間化して 10 分聞, 22 才の比較的発音の明暸な女性洞じ強さで 朗読させ、これをテープレューダーにて録音したすのを 用いた。

\section{4. 实施方法}

当教室所有の防音德力検盉音に简えられた，シールド 室内の椅子に被檢者を坐らせ，アルコールで上下眼简縁 中央を清拭し電極を食塩糊で接着，紙紏創套で固定した 後, 受話器を被檢耳に当てさせた，約 2 分安静にさせた 後，自発瞬目の記録を開始し直さに，テープレコーダよ り語音を䦪值下と思われる音仕で，10秒〜20 秒間与克 る. 反応力 (一) なら音制激の間隔を10〜20秒として $10 \mathrm{db}$ またわ $5 \mathrm{db}$ ステップの上昇法で与え，反応の有

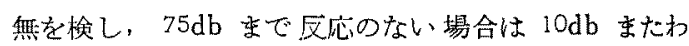
$5 \mathrm{db}$ ステップの下降法で反応の有無を検查した・この ようにして得られた反応陽性の最小のdbを本法による 闌值とした。本湘定は多くは5〜10分で終了した・次に 自覚的に語音が聞え始めた時と，关れを大体了解できた 時の值を被検者の応答で知り，前者を最小可聴閶，後者

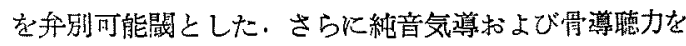
自覚法で測定した（骨導聴力は難聴型を知るために測定 された).

\section{第 3 章 実験成耫}

1. 正常聴力㨋についての実戨成績

(1) 反庄隄性率

30 例のらち，語音剌激に対して反応のあつたるのは 23 例 (76.6\%) であつた。

(2) 反応型式

反応のあつたもの〉らち，多くのものは自発瞬目が語 音刺激により抑制をらけたが (抑制型)，少数のbのに は自発瞬目が頿発するのが見られた（頻発型）。 
第 1 表 正常聴力者に括ける本法閶値々 自営法闎值との差 $(\mathrm{db})$

\begin{tabular}{|c|c|c|c|c|c|}
\hline \multirow{2}{*}{ No. } & \multirow{2}{*}{ 年令 } & \multirow{2}{*}{ 性 } & \multirow{2}{*}{ 純音聴力 } & \multirow{2}{*}{ 最小可聴閂 } & 闘 值 \\
\hline & & & & & 并別可能闇 \\
\hline 1 & 21 & 우 & 0.00 & 5 & 0 \\
\hline 2 & 21 & $\wp$ & 0.00 & 0 & -5 \\
\hline 3 & 21 & 우 & 0,00 & 0 & -5 \\
\hline 4 & 23 & 우 & 10.00 & 5 & 0 \\
\hline 5 & 21 & 우 & 0.00 & 5 & -10 \\
\hline 6 & 21 & q & 10.00 & 15 & 10 \\
\hline 7 & 31 & $\delta$ & 12.50 & 5 & -5 \\
\hline 8 & 41 & $\delta$ & 2,50 & 0 & -5 \\
\hline 9 & 22 & 우 & 0.00 & 0 & -5 \\
\hline 10 & 22 & 우 & 0.00 & 10 & 0 \\
\hline 11 & 26 & $\hat{\delta}$ & -5.00 & 0 & -5 \\
\hline 12 & 25 & 3 & 0.00 & 0 & $-: 5$ \\
\hline 13 & 21 & t & 0.00 & 5 & 0 \\
\hline 14 & 25 & 우 & 5.00 & 0 & -5 \\
\hline 15 & 29 & $\delta$ & 0.00 & 5 & 0 \\
\hline 16 & 41 & $\hat{\jmath}$ & 2.50 & 5 & 0 \\
\hline 17 & 32 & $\hat{\jmath}$ & 0.00 & 0 & -5 \\
\hline 18 & 17 & 우 & 0.00 & 10 & 0 \\
\hline 19 & 20 & $\delta$ & -5.00 & -5 & -10 \\
\hline 20 & 12 & $\hat{\delta}$ & 0.00 & 0 & -5 \\
\hline 21 & 20 & $\delta$ & -5.00 & -5 & -10 \\
\hline 22 & 50 & $q$ & 7.50 & 5 & 0 \\
\hline 23 & 22 & $\delta$ & 0.00 & 0 & -5 \\
\hline
\end{tabular}

i）抑制型：反応陽性の 23 例中 20 例 $(86.9 \%) に$ 見られた．代表的な反応例を第 2 图に示す。

ii）頻発型：反応陽性の 23 例中 3 例 $(13.1 \%)$ 飞見 られた，代表的な反応例を第 3 図に示す。

(3) 聴力測定成績

本法による測定可能例についての測定成縝怯第 1 表に 本法による閾值と自覚法による闒值との差をもつて示し た、これを度数分布で表したのが第2 表である。この表 の中で純音聴力とは， $0.5 \mathrm{Kcps}, 1 \mathrm{Kcps}$ および $2 \mathrm{Kcps} の$ 閾值をそれぞれ，a，b，cとし $\frac{a+2 b+c}{4}$ から求められ る実用聴力（森本, 志井田 ${ }^{16)}$ ) を示す.

（i）本法䦨值と自覚法間值との差（第 1 表）

この表から分ることは，本法閾值と純音平均㜇力との 差が（ $\leq 0)$ の值をとるものが 20 例 $(86.9 \%$ ) で維音聴 力の方が本法閾值上り良好なるのが大多数であつたと云 らことである。

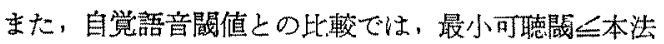

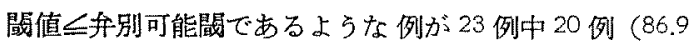
\%)で, 大多数のものに打いて本法間值は両者の中間に あることが判る。

（2）本法間値と自覚法閾値の差の度数分布(第 2 表) この表を作製する場合緇音の平均聴力は小数点以下第 I 位の数を四唅五入して分類した.ささらにこの表につい て， Odb を中心とする度数分布汇注目してみると，本 法閥值と純音聴力の羑が $0 \pm 2.5 \mathrm{db}$ 以内のむのは $56.5 \%$,

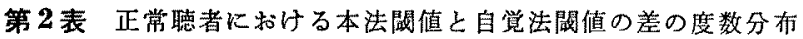

\begin{tabular}{|c|c|c|c|c|c|c|c|c|}
\hline$d b$ & $\begin{array}{l}<-15 \\
(+2.5)\end{array}$ & $\begin{array}{c}-10 \\
( \pm 2.5) \\
\end{array}$ & $\begin{array}{l}-5 \\
( \pm 2.5) \\
\end{array}$ & $\begin{array}{c}0 \\
( \pm 2.5) \\
\end{array}$ & $\begin{array}{c}5 \\
(-2.5) \\
\end{array}$ & $\begin{array}{c}10 \\
( \pm 2.5)\end{array}$ & $\begin{array}{c}15 \\
(-2.5)<\end{array}$ & 誩 \\
\hline 純音聴力 & 0 & 0 & 3 & 13 & 3 & 3 & 1 & 23 \\
\hline 最小可聴閔 & 0 & 0 & 2 & 10 & 8 & 2 & 1 & 23 \\
\hline 升別可能闒 & 0 & 3 & 11 & 8 & 0 & I & 1 & 23 \\
\hline
\end{tabular}

$0 \pm 7.5 \mathrm{db}$ 以内のものは $72.6 \%, 0 \pm 12.5 \mathrm{db}$ 以内のもの は95.6\%であり，平均して $1.5 \mathrm{db}$ たけ純音間值の方 がよいことがわかつた。 また語音最小可聴闎との差が $0 \pm 2.5 \mathrm{db}$ 以内のものは $43.4 \%, 0 \pm 7.5 \mathrm{db}$ 以内のものは $86.9 \%, 0 \pm 12.5 \mathrm{db}$ のものは95.6\% で平均して $1.5 \mathrm{db}$ た㤃自賞法の方がよく，また弁別可能閜との差が $0 \pm 2.5$ $\mathrm{db}$ 以内のものは $34.7 \% ， 0 \pm 7.5 \mathrm{db}$ 以内のものは 82.6 $\%, 0 \pm 12.5 \mathrm{db}$ 以内のものは $100.0 \%$ で平均して $3.3 \mathrm{db}$ だ本法の方が自営法よりよいといら成績となつた。

\section{2. 難聴者についての史験成續}

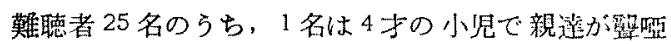
をらたがつて当科を受曑したもので，自覚法は不可能で あつたが本法によつて 80dbに明らかな反応が羿められ たものである、その他の，

他覚扣よび自覚法可能な24名については，

（1）反応陽性率

24 例中 17 例 $(71 \%)$ が語音刺激に対して反応を示し た（第 4 図，第 5 図，第 6 図). 


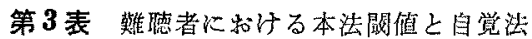
荫との盖 $(\mathrm{db})$

\begin{tabular}{|c|c|c|c|c|c|c|c|c|}
\hline \multirow{2}{*}{ No. } & \multirow{2}{*}{$\begin{array}{l}\text { 年 } \\
\text { 命 }\end{array}$} & \multirow{2}{*}{ 性 } & \multirow{2}{*}{ 紨舀聴力 } & \multicolumn{2}{|c|}{ 語音闎 值 } & \multirow{2}{*}{ 嚾 } & \multirow{2}{*}{ 聴 } & \multirow{2}{*}{ 㤠 } \\
\hline & & & & $\begin{array}{l}\text { 最 小 } \\
\text { 音聴闘 }\end{array}$ & 并，则 & & & \\
\hline 1 & 10 & $\delta$ & 8.75 & 0 & -5 & 伝 & & 音 \\
\hline 2 & 19 & q & 11.25 & 5 & 0 & & " & \\
\hline 3 & 44 & $\delta$ & 21.25 & 5 & 0 & & " & \\
\hline 4 & 20 & $q$ & 20.00 & 5 & 0 & & $"$ & \\
\hline 5 & 23 & $\delta$ & -2.50 & 5 & 0 & & $"$ & \\
\hline 6 & 20 & $\delta$ & 3.75 & -5 & -15 & 泚 & & 合 \\
\hline 7 & 12 & q & 7.50 & 0 & -15 & & $"$ & \\
\hline 8 & 19 & $\delta$ & -15.00 & -5 & -15 & & " & \\
\hline 9 & 42 & $\hat{o}$ & -16.25 & -5 & -20 & & $"$ & \\
\hline 10 & 50 & $\delta$ & 0.00 & 0 & -15 & & " & \\
\hline 11 & 75 & 우 & -2.50 & 25 & 10 & 感 & & 乓 \\
\hline 12 & 53 & $\delta$ & -31.25 & 0 & -20 & & $"$ & \\
\hline 13 & 22 & $\delta$ & 15.00 & 15 & 0 & & $"$ & \\
\hline 14 & 46 & $\delta$ & 12.50 & 10 & -5 & & " & \\
\hline 15 & 25 & 9 & 5.00 & 10 & 0 & & $"$ & \\
\hline 16 & 26 & $\delta$ & 1.25 & 10 & -5 & & $"$ & \\
\hline 17 & 5 & $\hat{\delta}$ & 2.50 & & & & $"$ & \\
\hline
\end{tabular}

(2) 反応型式

（i）䉼制型：扂応陽性の17 例中 13 例 $(76.5 \%) \mathrm{K}$ 見られた。

（ii）頿発型：反応陽性の17 例虫 4 例 $(23.5 \%) \mathrm{K}$ 見られた。

(3) 聴力測定成結

（i）本法間值と自覚法閾值との差（第3表）

この表より，本法閾値》礼音閶值であるよ5な例が 12 例 $(70.5 \%)$ あり, 最小可聴閔 $\leq$ 本法間值 $\leq$ 手别可能 間であるよらな例が 16 例中 12 例 (74.8\%) ある事がわ かる。

(ii) 本法閔值との差の度数分布（第 4 表）

この表より次の事がわかつた，才なわち，本法䎏值と 純音㯖力の美が $0 \pm 2.5 \mathrm{db}$ 以内のものは $11.7 \%, 0 \pm 7.5$ $\mathrm{db}$ 以内のものは $41.1 \%, 0 \pm 12.5 \mathrm{db}$ 以内のむのは 58.8

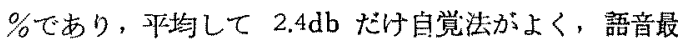
小可聴䦔との差が $0 \pm 2.5 \mathrm{db}$ 以内のものは $25 \%, 0 \pm 7.5$ $\mathrm{db}$ 以内のものは $68.9 \%, 0 \pm 12.5 \mathrm{db}$ 以内の6のは 62.5

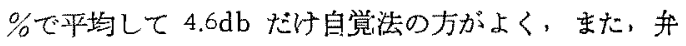
別可能闌との差が $0 \pm 2.5 \mathrm{db}$ 以内のものは $37.5 \%, 0 \pm$ $7.5 \mathrm{db}$ 以内のものは $56.2 \%, 0 \pm 12.4 \mathrm{db}$ 以内のものは

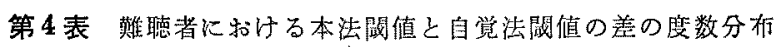

\begin{tabular}{|c|c|c|c|c|c|c|c|c|}
\hline $\mathrm{db}$ & $\begin{array}{l}<-15 \\
(+2.5) \\
\end{array}$ & $\begin{array}{c}-10 \\
( \pm 2.5)\end{array}$ & $\begin{array}{c}-5 \\
( \pm 2.5)\end{array}$ & $\begin{array}{c}0 \\
( \pm 2.5)\end{array}$ & $\begin{array}{c}5 \\
( \pm 2.5)\end{array}$ & $\begin{array}{c}10 \\
( \pm 2.5)\end{array}$ & $\begin{array}{c}15 \\
(-2.5)<\end{array}$ & 計 \\
\hline 純意咕力 & 3 & 0 & 2 & 2 & 3 & 3 & 4 & 17 \\
\hline 最小可聴闒 & 0 & 0 & 3 & 4 & 4 & 3 & 2 & 16 \\
\hline 加別可能關 & 6 & 0 & 3 & 6 & 0 & 1 & 0 & 16 \\
\hline
\end{tabular}

62.5\%で, 平均して6db だけ本法の方が占いといら成 績となつた。

\section{1. 実歌成績の総括}

正常聴力者 30 名 (12才〜 50才) と難恥者 25 名 (4才 〜 75才), 計 55 名の 55 耳につい, 語音を聴觉刺激と

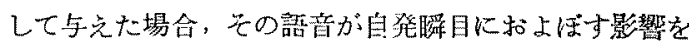
Electrooculogramにより誽察し，これを他覚的咕力检 查に応用しようとした。その結果、語音刺湤が自発瞬目 を抑制または非発することが判り，本法扰よび自覚法の 施行が可能であつた 54 例汸いては，反応陽性率では

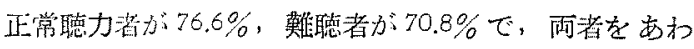
せて $74.0 \%$ であつた。このう占抑制型は，正常㯖力将 で $86.9 \%$ ，萁鱾者で $36.5 \%$ ，計 $82.5 \%$ であり，頻発型
は，正常聴力者で $13.0 \%$, 鹳聴者で $23.5 \%$, 計 $17.5 \%$ で あつた。本法間值と自覚法間值との比較では，本法閔值

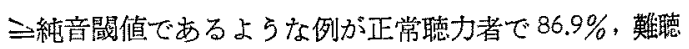

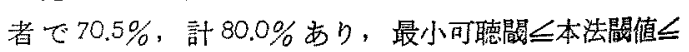
弁別可能阿である上うな例は正常聴力者で $86.9 \%$, 難聴 者で $74.8 \%$, 計 $82.1 \%$ であつた。本法闻值と自党法闒 值との差の度数分布では雨者の差が $0 \pm 12.5 \mathrm{db}$ である よらな例仗，純音聴力について、，正常聴力者 $95.6 \%$ ， 蕉聴者 $58.8 \%$, 計 $80.0 \%$ であり, 平均して $\{1.5 \mathrm{db}$ (正) $2.4 \mathrm{db}$ (難) $1.9 \mathrm{db}$ (計)\}だけ自覚法がよく，最小可聘 闖については，正党聴力者 $95.6 \%$ ，難聴者 $87.5 \%$ ，計 $92.3 \%$ であり, 平均して $\{2.8 \mathrm{db}$ (II) $4.6 \mathrm{db}$ (䓪) $3.7 \mathrm{db}$ (棓)\}だけ自覚法がよいか，弁別可能闒については，正 常聴力者 $100 \%$ ，難聴者 $62.5 \%$ ，計 $84.6 \%$ であり，灭妁 


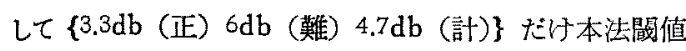
の方がい。

2. 他覚的語音聴力検查の文献的考察, ならびに 本法成績との比較

さて，先に緒言に拈いて述べたように，現在まで多く

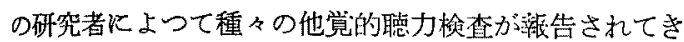
たが，その殆んどは純音を聴覚刺激として用いている。

しかし奉用的語音聴力を定量的に䂏るということも非常 に重要であることは，我々臨床家が日常経験するところ である、最近海外よりの文献に他覚的語音聴力検查の報 告が，2、3見られるようになつたのもこのよ5な理由に よるものと思われる，たとえば，Knapp 等10) は GSR を用いて語音に対する反忘を観察し，121 例中 106 例 (88\%)が闎值に羊した語音に対して明らかな反応を示し たといっている。本法の反応陽性率は $74.0 \%$ であつた。 たよ゙し，彼等はこの場合被検者が音に対して自覚的に応 答するよ5にあらかしめ命じて拈き，音比して皮有電 気反射が起り易い状態にしておくといら方法をとつてい る。な招，彼等のいら闒值と本法江打最小可聴闒と は同義であると考兄られる.Ruhm 等11)同しくGSR により語音を条件刺激とし電気ショックを無条体刺激と する条件反応を応用して聴力を泪定し，30 例中の 28 例 (93\%) K分化条件反心の形成に成功した．この5ち20 例 (71\%) が自覚的語音聴取闌値の $8 \mathrm{db}$ 以内にあつた。 本法では最小可聴䦪の $0 \pm 12.5 \mathrm{db}$ 以内にあるるのは $92.3 \%$ であつた. Whipple 等 ${ }^{12)}$ (4 40 名の正常聴力の 白人女性（17才〜25才）についてRuhm 等11) の方法 により追試を行い，他覚㡲值，自覚語音䦔值扣よび自覚

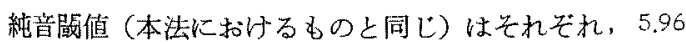
$\mathrm{db}, 6.50 \mathrm{db}$ および $5.81 \mathrm{db}$ であつたと云う.すなわち，

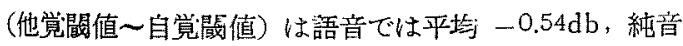
で恃平均 $0.17 \mathrm{db}$ である. 本法の正常聴力者 23 名につ いて見ると, 他覚閶值, 最小可聴間および純音閥値の平 均灶それぞれ $1.52 \mathrm{db} ，-0.87 \mathrm{db}$ 抢よび $0.43 \mathrm{db}$ であり （他喾間值〜自覚䦨值)は語音では平均 $2.39 \mathrm{db}$, 純音では 平均 $1.09 \mathrm{db}$ 、であつた。

\section{3. 本現象発現の機序}

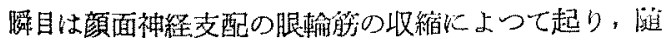
意的にもできる゙他方種々の原因によつて反射的にも引 起される。しかし通常みられる不随意的自発的な瞬目は 正常成人の場合，1分間13〜23回の割合で挌こること が知られている(南、等 17)).

瞬目の上位中枢は大脳にありこれれよつて自発瞬日
の頻度が統制されるという。しかし自発瞬目の機序はま だよくわかつていない，自発瞬目の機序がよくわからな いのに，音を聞かせた場合それがどらして抑制または促 進するかの機序を明らかにすることはできないわけであ るが，次江政光て考擦を加えてみたいと思ら。

Hernández-Peón, 等 ${ }^{18)}$ は無麻酔の猫の蝸牛神経核

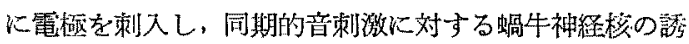
発電位を観察したところ，安静状態で梳研発電位は同振 幅で規則的に現われたが，二十日国を瓶に入れて猫の前 に置き猫，の注意をとれに向けさせたとこち，訪発電位 の振幅が著るしく減じ，二十日鼠を取り去り猫が安静に 戾ると砳発電位もまた旧復するのを観察したが，それ は特定の事物に対する注意集中により他の機能に対し， 脳幹網様体から抑制作用が働いたことによると説明して いる。この考えを今度の成績沙てはめれば，語音刺激 に注意を向けた事によつて自発瞬目が折制される現象は 一応説明されるように思われる。しかし自発瞬目の頻発 型の発現機序はこれでは説明ができない。これを説明す るのに都合の上い生理学的実鍳成續は見当らないが，若 乙自発瞬目が精神的與鹪によつて頻度が增与性質のもの であるとし，語音刺激が精神的與奮を起す上うな外的委 たわ内的条件のむとに与光られたとすれば，それによつ て自発瞬目の頻度がさらに增す可能性む考党られるわけ である，実際汇当つて被愉者の精神状態がどのようであ つたかの判定は困難であるので, 自発瞬目の頻発型の機 序は今迄の実験の範围では不明といわなければならな い.

\section{4. 本法に対する批判}

(1) 测定方法

無条件反応であるから測定の操作が容易であり，所要 時問も5〜10 分の短時間であるという利点を有する。

(2) 湘定成績

本章2、に述べた如く，語音を用いた他の研究者の成 頪と比べてみると，湘定成功率では彼等にや〉然るが， 反芯陽性な被検者心ついては，その閾值の信頼度，精度

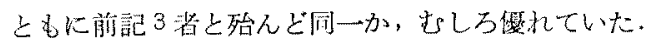

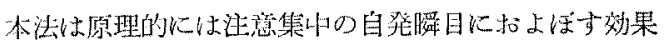

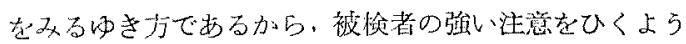
な語音剩湤を各被梌者の個体に応して適当に選んで与 点，末た，音に対して充分注意が向くような瀷境を作つ て検査を行うならば，さらに反応陽性率を高めることが できるむのと考古られる、たざし，この場合被検者の精 神的安静状態をきたさしめるよう充分な注意が肝要であ 


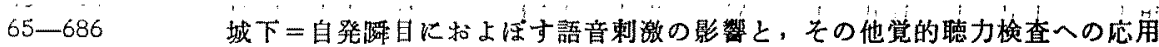

ろう。

\section{第 5 章 結語}

自発瞬目に拈よぼす語音刺舫の影響を Elect rooculogram 上に観察し，これの他覚的聴力検查への応用を試 济た。

(1) 被検者は正常聴力者 30 名之難聴者 25 名の計 55 名（4才〜75 才）の男女で，その片耳について湘定を抋 こない，同時に自賞的純音聴力执よび唔音聴力の剆定も 行つた.

（2）反応陽性例は，本法ならびに自覚法の施行可能な 54 例中 40 例 $(74 \%)$ で，語音により自発瞬目が抑制をら けものが 33 例 (82.5\%), かえつて頻発したるのが 7 例 (17.5\%) あつた。 この上らな反応の機序について考察 を加えた。

（3）純音平均㯖力との差が $0 \pm 12.5 \mathrm{db}$ 以内の むのは 32 例 $(80,0 \%)$, 語音最小呵倰閶との差が $0 \pm 12.5 \mathrm{db}$ 以内 のものは36 例 $(92.3 \%)$, 語音我別可能間との差が $0 \pm$ $12.5 \mathrm{db}$ 以内のものは 33 例 $(84.6 \%)$ であつた. 本法闘 值とこの3者との差は平均して， $1.9 \mathrm{db} ， 3.7 \mathrm{db}$ 扤よび $-4.7 \mathrm{db}$ であつた.

（4）湘定成功率の点で他の方法にや」劣るが精度につ いては満足すべき結果を得た。従つて本法は他覚的聴力 測定法の一つとして，今後検討する価值ある方法と思 亏.

\section{参考文 献}

1) Bordley, J. E.: An evaluation of the psychog. alvanic skin response technicues in audiometry, Laryngoskope, 66,1162〜1185，1955，2) 称本正紀， 志井田守：他覚的聴覚顿查の経験，耳鼻臨， 45, 60, 1952. 3) Goldstein, $R$., Effectiveness of conditioned electrodermal responses in measuring pure-tone threshold in cases of non-organic hearingloss, Lary.

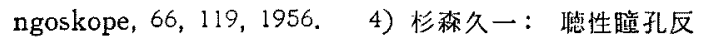
応に上る他覚的聴覚検査について, 耳嶴臨床, 52,818

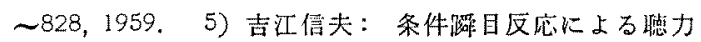
測定，日耳鼻，64，653～663，1961。6) 本川弘一：腷 波と条件反射, 腷砳究，7，1，1950，7) Karl-Heinz Hahlbrock: Die audiometrische prüfung des akustischen lidreflex, Arch. Ohr.-Nas.-,u. Kehlk-Heilk.Heilk. 174, 139 149, 1959. 8) 线输勲：音響刺激に 站する人間大脳誘発電位を観察するための一新方法につ いて，日耳率，62，1143，1959.99）下平正臣, 田中美
贸, 坂部長正：鈴木篤郎編, 他観的聴力測定, 第3 章, 聴性皮苚電気反応，1960，日耳奥信州地方会。10) $K n$ $a p p, P$., and Gold, B.: The galvanic skin response and diagnosis of hearing disorders, Dsychosom. med. 12, 6, 1950. 11) Howard, B. Ruhm, M.A., and Otto, J. Menzel, M.A.. Objective audiometry in cases of nonorganic hearing loss, A.M.A. Archi. ves of otolaryngology, 69, 212 219, 1959. 12) $\mathrm{Cli}$. fford, I. Whipple, and Frank Kodman: The validity of objective speech audiometry, The journal of laryngology and otology, $74,84 \sim 89,1960.13) D o$. nald, B. Lindsley: Attention, Consciousness, sleep and wakefulness, Handbook of physiology, section 1, 3, 1571，1960，14）本川弘一; 電気的实験法，138, 1953, 南山堂. 15)厇石怕; Electro-oculogram K関 する研究（第 1 䋧），日眼会甜，57，55，1953，16）森 本正紀, 志井田守：㥁力椧查の手引，13，1958，医学書 院. 17) 南能太, 山城主計, 南ミッ：踩目回数に䦎 する研究，臨林限科，11，1012１014，1957. Hernández-Peón, R., H Scherrer and $M$. Jouvet: Science, 123,331, 1955, cited by Donald, B. Lindsley. 1960 .

\section{付 图説明}

第 1 図 装置の Blockdiagram

第 2 図 (正常聴力者) Odb の語音刺激 (V.S.) に上 り自発瞅目 (S.B) は明らか飞抑制をらける も， $-5 \mathrm{db} の$ V.S. にはあまり著るしい㧕格 を示さない。

第 3 図 (正常聴力者) $5 \mathrm{db}$ の V.S. により S.B は明 らかに頻発するのがみられる。

第 4 図（伝音性難㯖者）35db の V.S 汶して S.B は抑制を示す。

第 5 図（混合性難㯖者）60db の V.S. に奶し S.B は明らかに抑制を示す。

第6 図（感音性難㯖者） $50 \mathrm{db}$ の V.S. 開始と共飞 S.B は抑制をらけた。

稿を終るに臨み，終始御孯第なる御指導上御校閲 を賜つな恩師平野新治教授並びに種々御助言を頂い た，本学第二生理学教室，藤森教授に感謝します。

（原稿到着 $=$ 昭和 37.2 .7 日） 

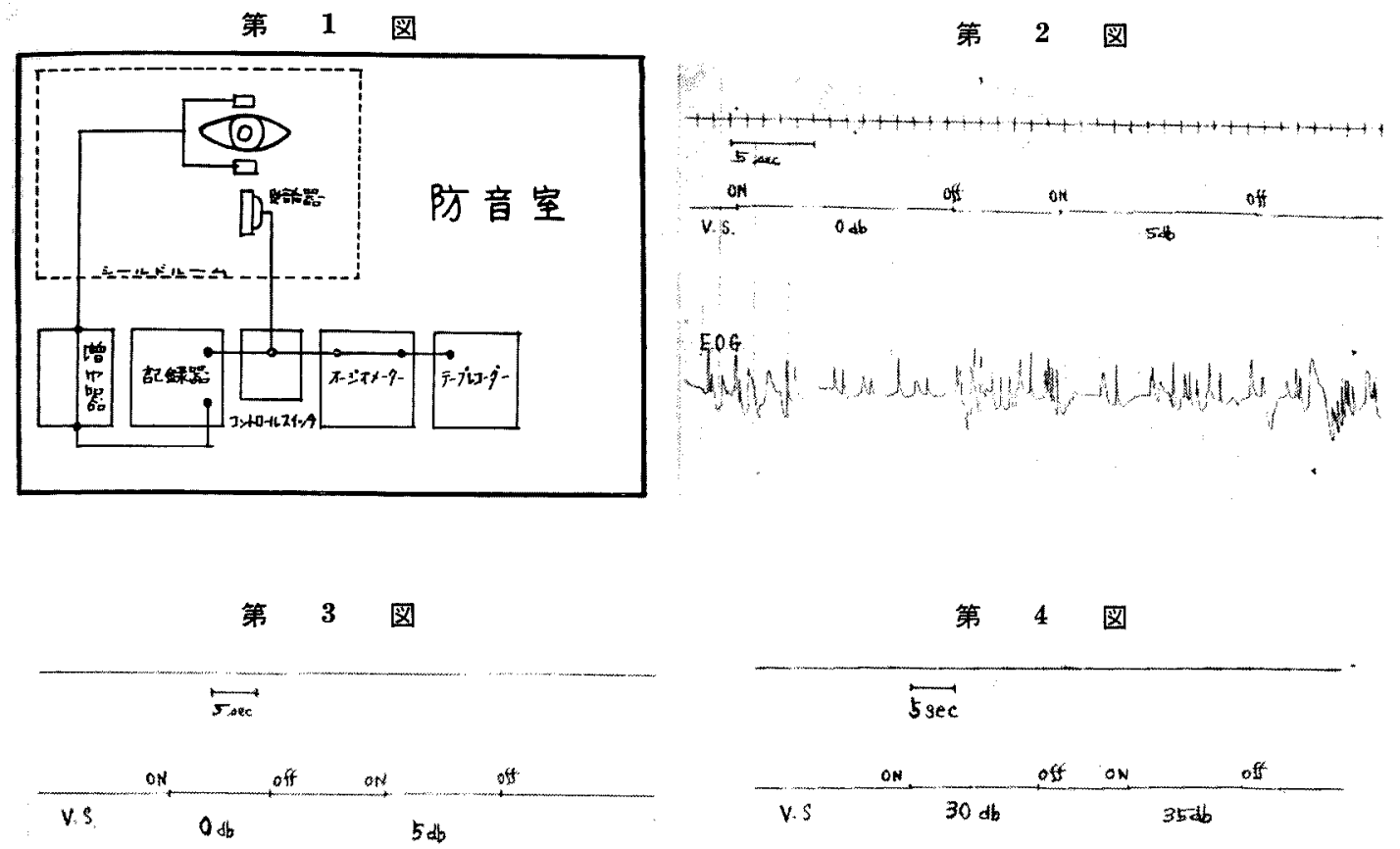

Mn

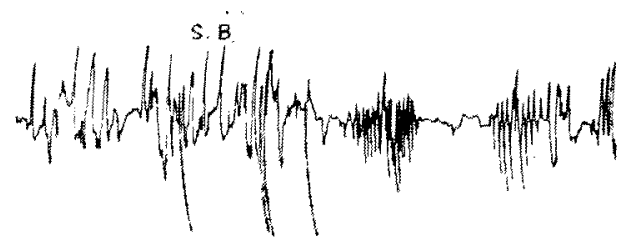

第 5 図

$$
\text { 第 } 6 \text { 図 }
$$

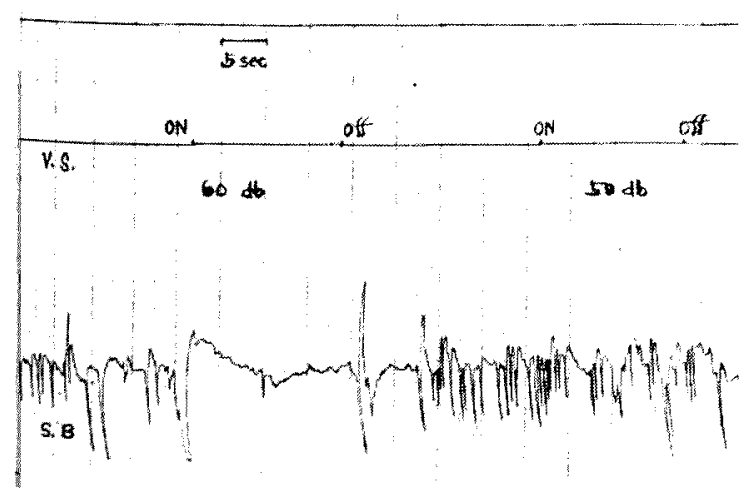

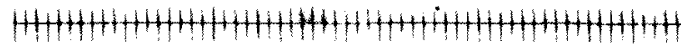
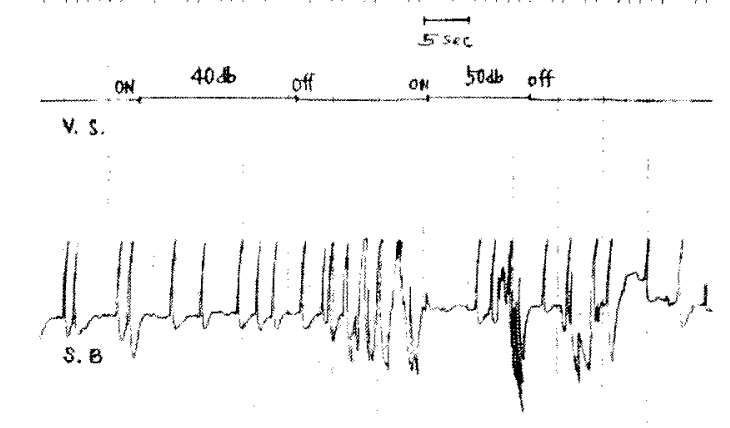